\title{
The Functions of the Amyloid Precursor Protein Gene and Its Derivative Peptides: I Molecular Biology and Metabolic Processing
}

\author{
Peter Konstantine Panegyres, Emily Rochelle Atkins
}

Neurodegenerative Disorders Research Pty Ltd, Subiaco, Australia.

Email: publications@panegyres.com.au

Received November $30^{\text {th }}, 2010$; revised February $18^{\text {th }}, 2011$; accepted March $1^{\text {st }}, 2011$.

\begin{abstract}
The amyloid precursor protein gene (APP) and its derivative peptides have important functions in the central nervous system. APP and A $\beta$ fulfil criteria as neuractive peptides: presence, release and identity of action. A $\beta$ is a peptide of 1 43 amino acids in length, derived from APP and the major component of the core of neuritic plaques found in Alzheimer's disease. Analysis of the cDNA of A $\beta$ revealed its origins from the larger precursor protein. There are at least four types of mRNA generated by alternative splicing of exons 7 and 8. Exon 7 encodes a 57 amino acid sequence found in the extracellular domain with major homology to the Kunitz-type of serine protease inhibitors. APP is cleaved by three secretases known as $\alpha, \beta$ and $\gamma$ secretase which act on APP at different sites producing various fragments of differing amino acid length. The $\gamma$ secretase is a macromolecular enzyme complex composed of presenilin 1, 2 and other molecular constitutents essential for its function.
\end{abstract}

Keywords: Amyloid Precursor Protein Gene, Biochemistry

\section{Introduction}

The amyloid precursor gene (APP) has important functions in the central nervous system. In Alzheimer's disease (AD) APP is the precursor of amyloid peptides (A $\beta)$ which forms the amyloidogenic cores of neuritic plaques, hallmarks of the disease. Understanding of the normal function of APP and its pharmacology will provide insights into the pathophysiology of $\mathrm{AD}$ and its treatment.

\section{Molecular Biology of APP}

$\mathrm{AD}$ is characterized by neuronal loss, senile plaques, and neuro-fibrillary tangles [1]. The major component of senile plaques is amyloid $[2,3]$. Amyloid is an insoluble extracellular protein that forms $\beta$-pleated sheets. This protein had become known as $\mathrm{A} \beta$ peptide and is $4-4.3$ $\mathrm{kDa}$ in molecular weight and is composed of $40-43$ amino acids.

Analysis of the cDNA revealed that it originated from a larger precursor molecule of about 700 amino acids termed the Amyloid Precursor Protein (APP) [4,5]. APP gene transcripts were identified in human brain [6]. APP is also found in the peripheral nervous system and skeletal muscle [7]. When APP was identified in virtually all cell types, and in all mammals and vertebrates tested, the term APP became widely accepted [8-10].

Examination of the hydrophobicity plot indicated that APP was a single-chain surface membrane-spanning peptide with a large extracellular and smaller cytoplasmic domain suggestive of a cell-surface receptor [11], the $\mathrm{A} \beta$ region being both in the extracellular and transmembrane domains.

Analysis of other cDNA clones revealed at least four types of mRNAs generated by alternative splicing of exons 7 and 8 [12-16].

The different forms of APP are designated by the number of amino acids: APP 695, APP 714, APP 751 and APP 770. Other isoforms have been discovered which result from differential splicing of exon 15 and are found in lymphocytes, macrophages and microglial cells —designated appican or L-APP $[17,18]$. The splicing of exon 15 determines the chondroitin sulfate attachment site of APP [19].

Trophic factors like NGF may also influence the splicing of APP and may be important in apoptosis and the mechanisms of neurodegeneration [20]. Splicing of APP may be modulated by acetylcholine nicotinic re- 
ceptor modulation [21]. APP 770 is mostly found in tissues outside the CNS and contains both exons 7 and 8 . These splice variants are regulated during development [22-24].

Exon 7 encodes a 56 amino acid sequence found in the extracellular domain that produces a region with major homology to the Kunitz-type of serine protease inhibitors (KPI) [25-28].

Hence:

APP 751 and $770=$ KPI +

APP 695 and $714=$ KPI -

This KPI+ domain was found to be identical to protease nexin II secreted by activated astrocytes [27,29]. Protease nexin II has powerful antichymotrypsin activity in vitro [30]. (Figure 1).

The $5^{\prime}$ upstream regulatory region of APP has been cloned and sequenced in rats and humans [31,32]. Rat APP has $97 \%$ homology to human APP, making it an excellent experimental animal to investigate the functions of APP $[15,33]$. There is significant homology in the APP promoter between monkeys and humans [34]. The regulatory region is high in $\mathrm{G}$ and $\mathrm{C}$ content, and has consensus DNA sites for AP-1, AP-2, AP-4, GCF and SP-1 proteins; it does not have a TATA or CAAT box [32-36]. These features establish APP as a house-keeping gene. Such genes are functionally required in all cell types irrespective of the specialized role of these cells. Other examples of housekeeping genes are vimentin and nerve growth factor (NGF) receptor genes. In vitro studies suggest that DNA methylation may affect APP gene expression by interaction with the GC-rich sequence [37] The promoter region of APP also contains recognition sequences for the heat-shock control element binding protein upstream of the RNA start sites. The heat-shock consensus sequence (CTGGACTTTTCTAG) is located at position $-317 \mathrm{bp}$ in the regulatory elements of APP [38].

When the promoter region was fused with chloramphenicol acetyltranferase (CAT) reporter gene and the function genes transfected into cell lines, deletional analysis revealed a negative regulatory element between -153 and -100 base pairs (bp) which contains two nuclear protein binding sites, one of which is probably SP1 [39].

An analysis of the APP promoter revealed that sequences -203 to +104 were sufficient for promoter function and regulatory elements were found from -128 to -63 ; furthermore the same proximal elements were recognised by nuclear factors from both neuronal and non-neuronal cells [40].

In the rat promoter region a position $375 \mathrm{bp}$ upstream of the start codon drives APP expression and is regulated by two sites at -260 to -248 and -223 to -192 [41]. Levels of APP mRNA may be modulated by cystolic protein-RNA interactions involving AU-rich regions and a 29 base element in the 3' nontranslated region $[42,43]$. Analysis of the rat promoter showed that the CAA and GAG regions interact with SP1, nuclear proteins, and human upstream stimulatory factor (USF) protein; furthermore the SP1 and USF sites regulate transcription of the CAA element $[44,45]$. The transcriptional regulatory factor NF-kappa-B/Rel recognises sequences in the $5^{\prime}$ regulatory region which specifically interact with $\mathrm{p} 50$ containing members of this family (p50/p50; p50/p65; p50/crel). The nuclear complex binding APP-kappa-B sites is an integral component of neurons and lymphocytes [46]. Interleukin- $\beta$ and glutamate may activate the NF-kappa-B/Rel binding site [47].

In a mouse embryonal carcinoma line it was shown that alternative splicing of APP pre-mRNA was influenced by the immediate early gene c-jun in that the encoding exons 7 and 8 were preserved maintaining greater relative amounts of APP 770 in comparison to APP695 [48]; this change impairing the ability of these cells to differentiate into neurons. A protein homologous to the ubiquitin activating enzyme $\mathrm{E} 1$ has been found to bind to the carboxyl terminal of APP and may be important in regulating its function [49].

In a study using Cos- 1 and P19 cells it was shown that exogenous APP mRNA may regulate its own expression. Cells over-expressing sAPP $\beta 770$ and $\operatorname{sAPP} \beta 695$ had reduced levels of sAPP $\beta 770$ and $\operatorname{sAPP} \beta 695$ mRNA [50]. There is no evidence that aluminium influences the expression of APP [51]. Phosphorylation may influence the expression of APP through kinase activity [52]. The transcriptional regulation of APP may be through the action of cyclic AMP and may be mediated by two sites on APP promoter not involving AP-2 sites [53-55].

APP mRNA may be regulated by nucleolin and heterogeneous nuclear ribonucleoprotein (hnRNP) through post-transcriptional interaction with the three untranslated regions of APP mRNA [56].

Further studies have shown that APP is a member of a family of structurally related proteins in mammals and other species. APLP 1 and 2 do not have the $\mathrm{A} \beta$ region [17,57-59]. APLP 2 may have a role in axogenesis in the olfactory epithelium [60]. APLP1 is found in the cerebral cortex postsynaptic density of rats and humans and supports a role in synaptic function [61]. Mouse cortical neurons lacking APP reveal normal neurite growth suggesting that APLP 1 and 2 might supplement this function of APP [62]. The protein and mRNAs for APLP1 and 2 are found in a similar distribution in human brain as APP providing further evidence for similarity of func- 


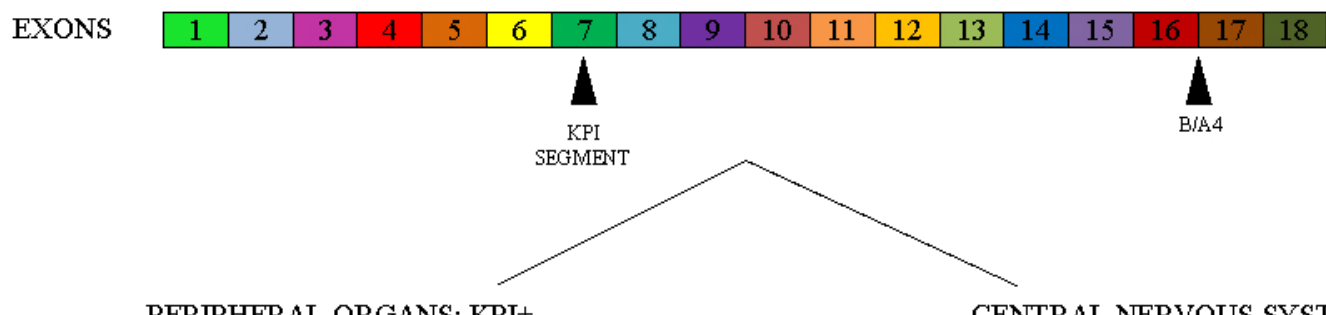

PERIPHERAL ORGANS: KPI+

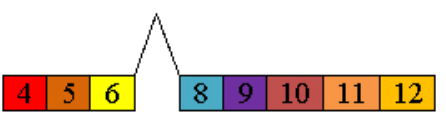

APP 751

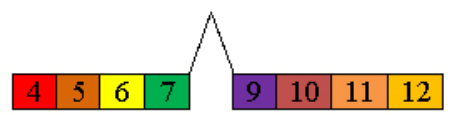

APP 695

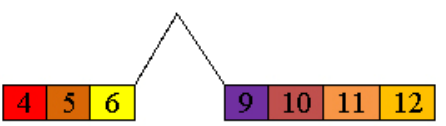

Figure 1. Exon structure of APP transcripts. These are generated by alternative splicing of exons 7 and 8 . Exon 7 codes for the KPI segment and exon 8 for the MRC OX-2 antigen. Transcripts containing exon 7 are found in peripheral organs, whilst exon 7 is absent in the CNS transcripts. Alternative splicing of exon 15 from all of the above transcripts generates mRNA isoforms, found by RT-PCR, in most tissues except neurons [17]. The $\beta / A 4$ encoding sequence is shared between exons 16 and 17. The transmembrane segment is encoded by exon 17.

tion [63]. APLP2 can provoke neurite outgrowth in chick sympathetic neurons as does $\operatorname{sAPP} \beta 695$ and 751 again suggesting redundancy of function [64]. The function of APLP molecules may be to supplement the functions APP in times of homeostatic stress. That is, a duplication of function.

\section{The Metabolic Processing of APP}

APP is proteolytically cleaved by a number of membrane bound putative enzymes known as secretases [65-68]. Protein phosphorylation is also important in the secretory processing of APP through the action of protein kinase $\mathrm{C}$ [69]. The $\beta$ secretase has been isolated, cloned, and sequenced [70].

The action of $\alpha$ secretase produces an $\mathrm{N}$-terminal fragment known as $\operatorname{sAPP} \alpha$ and a C-terminal fragment which remains in the membrane. The $\alpha$-secretase may act in the presence of different amino acid sequences in the juxta-membranous region of APP [71].

The $\beta$-secretase acts at the N-terminal end of the $\mathrm{A} \beta$ domain and produces $\operatorname{sAPP} \beta$ which contains the undisrupted $\mathrm{A} \beta$ region. The activity of the $\beta$-secretase may depend on the primary structure of APP [72]. The action of $\gamma$-secretase cleaves the $\mathrm{C}$-terminal end of $\mathrm{A} \beta$ from the $\mathrm{C}$-terminal fragment of $\operatorname{sAPP} \beta$. Cleavage of the N-terminal domain of $\mathrm{A} \beta$ is essential for its secretion [73].
APP is found in neuronal cell membranes [74]. APP is metabolized in the Golgi apparatus and progresses to the liposomes for degradation and to the plasma membrane for secretion [75-77]. The activation of protein kinase $C$ regulates the production of $\operatorname{sAPP} \beta$ and decreases $\mathrm{A} \beta$ in Golgi secretory vesicles [78]. The $\beta$-secretase cleavage may also occur in the Golgi apparatus [79]. The regions which determine secretion are in the extracellular domain [80]. Secretory vesicle budding and trafficking is not essential for $\gamma$-secretase action which can occur in the trans-Golgi network [81].

$\beta$-secretase activity resides in the late endosomal compartment and a $\gamma$-cleavage in early endosomes generating $\mathrm{A} \beta$ peptides [82]. The endoplasmic reticulum and secretory vesicles generate $\mathrm{A} \beta(1-42)$, the trans-Golgi network $A \beta(1-40)$ suggesting that intracellular organelles produce $\mathrm{A} \beta$ of differing amino acid lengths [83].

Recently sumoylation, the covalent process which modifies cellular proteins with small ubiquitin-like modifier (SUMO) proteins and enhances their stability or modulates subcellular compartmentalization, has been shown to regulate secretase cleavage of APP. Augmentation of SUMO3 was shown to reduce $\mathrm{A} \beta$ by production by enhancing the function of the $\alpha$-secretase [84]. SUMO2 was shown to inhibit $\beta$ secretase leading to the possibility that agents acting on SUMO 2 might decrease $\mathrm{A} \beta$ pro- 
duction in $\mathrm{AD}$.

A major advance was the discovery that presenilin 1 (PS1) and APP interact in the endoplasmic reticulum and Golgi where PS1 is essential for $\gamma$-secretase activity on C-terminal fragments of APP and the generation $\mathrm{A} \beta[85]$. Mutations in PS1 increase the production of $A \beta 1-42$ in cultured cells and knock-out mice not containing PS1 gene do not produce $\mathrm{A} \beta[86,87]$. PS1 is required for the proper $\gamma$-secretase processing of APP C-terminal fragments, however the role of PS1 in the physiological function of APP is unknown and its role in sporadic AD is not understood $[88,89]$. The effect of PS1 is independent of endoplasmic trafficking of APP [90]. The relationship of PS1 to the processing of APP processing is similar to the metabolism of cholesterol which is regulated by proteolysis of a membrane-bound transcription factor through the action of a metalloprotease - the sterol regulatory element binding protein (SREBP). M19 cells deficient in the S2P gene, which encodes a metalloprotease essential for the proteolysis of SREBP, does not produce $\mathrm{A} \beta$ indicating there may be homology with this metalloprotease and the putative $\gamma$-secretase [91]. These findings strongly support the notion that presenilin proteins are important in the proteolytic processing of APP.

Presenilin (PS) proteins have homology to Notch genes. Notch genes are involved in intracellular signalling and development and may have important roles in the physiological regulation of differentiation within the haemopoietic system. These functional properties may limit the development of compounds which antagonize the actions of PS proteins. Mutagenesis experiments of two transmembrane aspartates in PS1 and PS2 abrogate $\gamma$-secretase activity and the production of $\mathrm{A} \beta$ suggesting that aspartate sites are critical in the proteolytic cleavage of APP [92]. PS1 mRNA is found in the same neurons as APP [93] and PS1 is identified in endoplasmic reticulum, Golgi apparatus and N-terminal fragments are found in synaptic organelles [94]. The $\gamma$-secretase is a multimolecular complex composed of PS1, 2, nicastrin, APH-1 and PEN-2 [95]. (Figure 2)

There may be a stoichometric interaction between APP and PS as both of these proteins form complexes with each other in living cells $[96,97]$. There may also be an interaction between these proteins at the cell surface which may be important in cell-cell adhesion and signalling since this protein complex activates tyrosine kinase [98].

The metabolic handling of APP by $\gamma$-secretase is probably distinct from endoplasmic reticulum processing [99]. The C-terminal fragment is important in trafficking and secretion of APP [100]. The action of cAMP-dependent protein kinase $\mathrm{A}$ influences the processing of

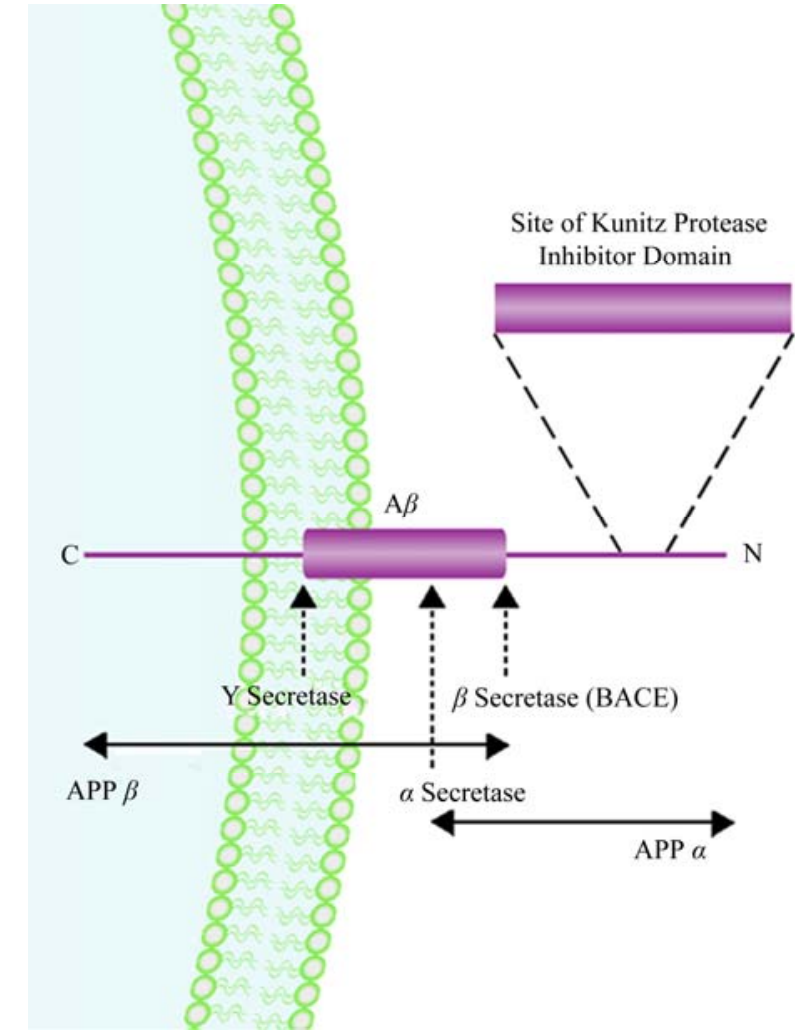

Figure 2. The structure of the amyloid precursor protein and its enzymatic cleavage. The largest transcript has $\mathbf{7 7 0}$ amino acids, the smallest 677 , after alternative splicing of exons 7, 8, and 15. Two alternative spliced exons of 56 and 19 amino acids are inserted at residue 289 , the first of these exons (exon 7) codes for the serine protease inhibitor domain of the Kunitz type (KPI) located in the extracellular domain. The amyloidogenic fragment $\mathrm{A} \beta$ has 28 amino acids in the extracellular domain with the next 11-15 in the transmembrane segment. The single transmembrane region is from positions 700 - 723. Alpha sectretase cleavage after position 687 yields soluble APP alpha ( $\operatorname{SAPP} \alpha$ ) which is found in body fluids; the 83 amino acid fragment remains in the membrane. Cleavage before position 671 generates a $12 \mathrm{kDa}$ fragment soluble APP beta (sAPP $\beta$ ) which contains the undisrupted sequence of $A \beta$ and serves as an intermediate in the production of free $A \beta$ through the action of beta-secretase (BACE). The site of action of the gammasecretase at the $C$-terminal end of the $A \beta$ membrane is shown. There is a $\mathbf{1 7}$ amino acid signal peptide at the $\mathrm{N}$ terminal.

APP towards $\operatorname{sAPP} \alpha$, decreasing both $\operatorname{sAPP} \beta$ and reducing $\mathrm{A} \beta[101]$.

The heparin binding consensus sequence VHHQKL also contains the $\alpha$-secretase cleavage site [102,103]. Levels of iron may modulate $\alpha$-secretase activity through inhibitory action of an iron response element [104]. A protease has been associated with acetylcholinesterase which releases APP from the cell membrane and may 
regulate APP secretion in amyloid plaques [105]. If energy metabolism is inhibited in the cell the secretase handling of APP is modulated such that more $\mathrm{A} \beta$ is produced [106]. A detergent-insoluble glycolipid-enriched membrane domain (DIG) contains $\mathrm{A} \beta$, PS1 and APP suggesting that it is within the intramembranous compartment that the cleavage of APP occurs [107].

APP might regulate its own metabolism such that KPI+ isoforms may decrease $\alpha$-secretase activity and increase the production of amyloidogenic $\mathrm{A} \beta(1-42)$ [108]. This finding has therapeutic implications for AD and requires further analysis at a gene expression level as this may lead to a new approach to treatment [109]. In human platelets APP is cleaved near the transmembrane region and involves $\mathrm{Ca}^{2+}$ dependent cysteine proteases $[110,111]$. The expression of human APP in yeast reveals that $\alpha, \beta$ and $\gamma$-secretases are conserved in yeast and their action might be linked to glycosyl-phosphatidylinositol on the cell surface $[112,113]$.

Other enzyme systems may be involved in the metabolism of APP and are of uncertain functional significance; these include a non-lysosomal multicatalytic proteinase (ingensin) [114]. Cathepsin B also has $\gamma$-secretase activity [115]. Metallopeptidases, similar to neuropeptidases, have been identified which cleave APP at a lys-leu-region [116,117]. Experiments with phosphoramidon, a proteinase inhibitor, further support a role for metalloproteases in the production of $\mathrm{A} \beta[118]$. Cathepsin $\mathrm{D}$ and $\mathrm{S}$ lysosomal enzymes have activities supportive of a role as $\gamma$-secretases $[119,120]$. Other cathepsins E and B may also be involved in the amyloidogenic processing of APP [121].

A gelatinase in HeLa cells possesses $\beta$-secretase like activity [122]. Zyme, a serine protease inhibitor in perivascular and microglial cells may also be involved in the metabolism of APP [123]. Tumour necrosis factor must also affect the $\alpha$-secretase cleavage of APP [124]. The proteolytic processing of APP by caspases may occur in the cytoplasmic domain and be activated in the presence of PS2 mutations leading to an increase in C-terminal fragments and $\mathrm{A} \beta$ leading to neuronal death [125].

Other proteins bind to APP which may be important in its metabolism include thrombin [126], the chaperone protein BiP/GRP78 [127], X11 $\alpha$ [128,129], PAT1 a microtubule-interacting protein which recognizes the basolateral sorting signal peptide of APP [130], UV-DDB (ultra-violet damaged DNA binding protein) binds to the APP YENPTY sequence in its cytoplasmic domain and may be involved in internalization and secretion of APP [131], and a novel XII like neuron specific protein with PDZ domains which interacts with the NPXY motif of APP and regulates phosphatidyl-inosityl binding to APP
[132].

The protease inhibitor KPI+ domain of APP has been shown to inhibit the processing of a proenkephalin processing enzyme prohormone thiol protease (PTP) and APP $\mathrm{KPI}+$ colocalizes with PTP and met-enkephalin in secretory vesicles [133]. PTP may therefore be the first physiological substrate of the protease inhibitor isoforms of APP.

\section{REFERENCES}

[1] A. Alzheimer, "Uber Eine Eigenartige Erkrankung Der Hirnrinde. Allgemeine Zeitsch Psych Psychisch-Gerichtichliche Med LXIV," 1907, Translated in: K. Bick, L. Armaducci and G. Pepeu, Eds., The Early Story of Alzheimer's Disease, Livinia Press, Italy, 1987, pp 1-3.

[2] G. G. Glenner and C. W. Wong, "Alzheimer's Disease: Initial Report of the Purification and Characterization of a Novel Cerebro-Vascular Amyloid Peptide," Biochemical and Biophysical Research Communications, Vol. 120, No. 3, 1984, pp. 885-890. doi:10.1016/S0006-291X(84)80190-4

[3] C. L. Masters, G. Simms, N. A. Weinman, G. Multhaup, B. L. McDonald and K. Beyreuther, "Amyloid Plaque Core Protein in Alzheimer disease and Down syndrome," Proceedings of the National Academy of Sciences of the United States of America, Vol. 82, No. 12, 1985, pp. 4245-4249. doi:10.1073/pnas.82.12.4245

[4] J. Kang, H. G. Lemaire, A. Unterbeck, J. M. Salbaum, C. L. Masters, K. H. Grzeschik, G. Multhaup, K. Beyreuther and B. Muller-Hill, "The Precursor of Alzheimer's Disease Amyloid A4 Protein Resembles a Cell Surface Receptor," Nature, Vol. 325, 1987, pp. 733-736. doi: $10.1038 / 325733 \mathrm{a} 0$

[5] D. J. Selkoe, M. B. Podlisny, C. L. Joachim, E. A. Vickers, G. Lee, L. C. Fritz and T. Oltersdorf, "B-Amyloid Precursor Protein of Alzheimer Disease Occurs as 110-135 Kilo-Dalton Membrane-Associated Proteins in Neural and Nonneural Tissues," Proceedings of the $\mathrm{Na}$ tional Academy of Sciences of the United States of America, Vol. 85, No. 19, 1988, pp. 7341-7345. doi:10.1073/pnas. 85.19 .7341

[6] R. L. Neve, E. A. Finch and L. R. Dawes, "Expression of the Alzheimer Amyloid Precursor Gene Transcripts in the Human Brain,” Neuron, Vol. 1, No. 8, 1988, pp. 669-667. doi:10.1016/0896-6273(88)90166-3

[7] S. S. Sisodia, E. H. Koo, P. N. Hoffman, G. Perry and D. L. Price, "Identification and Transport of Full-Length Amyloid Precursor Proteins in Rat Peripheral Nervous System," Journal of Neuroscience, Vol. 13, No. 7,1993, pp. 3136-3142.

[8] J. P. Anderson, L. M. Refoldo, W. Wallace, P. Mehta, M. Krishnamurthi, J. Gotlib, L. Bierer, V. Haroutunian, D. Perl and N. K. Robakis, "Differential Brain Expression of the Alzheimer's Amyloid Precursor Protein," EMBO Journal, Vol. 8, No. 12, 1989, pp. 3627-3632. 
[9] R. W. Manning, C. M. Reid, R. A. Lampe and L. G. Davis, "Identification in Rodents and Other Species of an Mrna Homolgous to the Human $\beta$-Amyloid Precursor," FEBS Letters, Vol. 427, No. 3, 1998, pp. 367-370.

[10] C. A. Sprecher, F. J. Grant, G. Grimm, P. J. O’Hara, F. Norris, K. Norris and D. C. Foster, "Molecular Cloning of the CDNA for a Human Amyloid Precursor Protein Homolog: Evidence for a Multigene Family," Biochemistry, Vol. 32, No. 17, 1993, pp. 4481-4486. doi:10.1021/bi00068a002

[11] J. Kang and B. Müller-Hill, "Differential Splicing of Alzheimer's Disease Amyloid A4 Precursor RNA in Rat Tissues," Nature, Vol. 325, 1987, pp. 733-736. doi:10.1038/325733a0

[12] T. E. Golde, S. Estus, M. Usiak, L. H. Younkin and S. G. Younkin, "Expression of B Amyloid Protein Precursor mRNAs: Recognition of a Novel Alternatively Spliced Form and Quantitation in Alzheimer's Disease Using PCR," Neuron, Vol. 4, No. 2, 1990, pp. 253-267.

[13] N. Kitaguchi, Y. Takahashi, Y. Tokushima, S. Shiojiri and H. Ito, "Novel Precursor of Alzheimer's Disease Amyloid Protein Shows Protease Inhibitor Activity," $\mathrm{Na}$ ture, Vol. 331, 1988, pp. 530-532. doi:10.1038/331530a0

[14] G. Konig, U. Monning, C. Czech, R. Prior, R. Banati, U. Schreiter-Gasser, J. Bauer, C. L. Masters and K. Beyreuther, "Identification and Differential Expression of a Novel Alternative Splice Isoform of the BA4 Amyloid Precursor Protein (APP) mRNA in Leukocytes and Brain Microglial Cells," Journal of Biological Chemistry, Vol. 267, No. 5, 1992, pp. 10804-10809.

[15] J. Kang and B. Muller-Hill, "Differential Splicing of Alzheimer's Disease Amyloid A4 Precursor RNA in Rat Tissues-Pre A4695 is Predominantly Produced in Rat and Human Brain," Biochemical and Biophysical Research Communications, Vol. 166, No. 3, 1990, pp. 1192-1200. doi:10.1016/0006-291X(90)90992-V

[16] R. E. Tanzi, J. F. Gusella, P. C. Watkins, G. A. Bruns, P. St George-Hyslop, M. L. Van Keuren, D. Patterson, S. Pagan, D. M. Kurnit and R. L. Neve, "cDNA, mRNA Distribution, and Genetic Linkage Near the Alzheimer Locus," Science, Vol. 235, No. 4791, 1988, pp. 880-884. doi:10.1126/science. 2949367

[17] R. Sandbrink, C. L. Masters and K. Beyreuther, "BA4Amyloid Protein Precursor mRNA isoforms without Exon 15 are Ubiquitously Expressed in Rat Tissues Including Brain, But Not in Neurons," Journal of Biological Chemistry, Vol. 269, No. 2, 1994, pp. 1510-1517.

[18] R. Sandbrink, C. L. Masters and K. Beyreuther, "APP Gene Family Alternative Splicing Generates Functionally Related Isoforms," Annals of the New York Academy of Sciences, Vol. 777, No. 1, 1996, pp. 281-287. doi:10.1111/j.1749-6632.1996.tb34433.x

[19] M. N. Pangalos, S. Efthimiopoulos, J. Shioi and N. K. Robakis, "The Chondroitin Sulfate Attachment Site of Appican is Formed by Splicing Out Exon 15 of the Amyloid Precursor Gene," Journal of Biological Chemistry, Vol. 270, No. 18, 1995, pp. 10388-10391.

\section{doi:10.1074/jbc.270.18.10388}

[20] W. Araki and R. J. Wurtman, "Increased Expression of Amyloid Precursor Protein and Amyloid Precursor-Like Protein 2 during Trophic Factor Withdrawal-Induced Death of Neuronal PC12 Cells," Molecular Brain Research, Vol. 56, No. 1, 1998, pp. 169-177. doi:10.1016/S0169-328X(98)00050-3

[21] L. M. Monteggia, S. P. Arneric and T. Giordana, "Nicotine Effects on the Regulation of Amyloid Precursor Protein Splicing, Neurotrophin and Glucose Transporter RNA Levels in Aged Rates," International Journal of Developmental Neuroscience, Vol. 12, No. 12, 1994, pp. 133-141. doi:10.1016/0736-5748(94)90006-X

[22] J. Apelt, R. Schliebs, M. Beck, S. Rossner and V. Bigl, "Expression of Amyloid Precursor Protein Mrna Isoforms in Rat Brain is Differentially Regulated during Postnatal Maturation and by Cholinergic Activity," International Journal of Developmental Neuroscience, Vol. 15, No. 1, 1997, pp. 95-112. doi:10.1016/S0736-5748(96)00073-1

[23] Y. Ohyagi, K. Takahashi, M. Kamegai and T. Tabira, "Developmental and Differential Expression of Beta Amyloid Protein Precursor mRNAs in Mouse Brain," Biochemical and Biophysical Research Communications, Vol. 167, No. 1, 1990, pp. 54-60. doi:10.1016/0006-291X(90)91729-C

[24] C. A. Sherman and G. A. Higgins, "Regulated Splicing of the Amyloid Precursor Protein During Postnatal Development of the Rat Basal Forebrain," Developmental Brain Research. Vol. 66, No. 1, 1992, pp. 63-69. doi:10.1016/0165-3806(92)90141-I

[25] N. Kitaguchi, Y. Takahashi, Y. Tokushima, S. Shiojiri and H. Ito, "Novel Precursor of Alzheimer's Disease Amyloid Protein Shows Protease Inhibitor Activity," Nature, Vol. 331, 1988, pp. 530-532. doi:10.1038/331530a0

[26] T. Oltersdorf, L. C. Fritz, D. B. Schenk, I. Lieberburg, K. L. Johnson-Wood, E. C. Beattie, P. J. Ward, R. W. Blacher, H. F. Dovey and S. Sinha, "The Secreted Form of the Alzheimer's Precursor Protein with the Kunitz Domaini Protease Nexin II," Nature, Vol. 341, pp. 144-147. doi:10.1038/341144a 0

[27] P. Ponte, P. Gonzalez-Dewhitt, J. Schilling, J. Miller, D. Hsu, B. Greenberg, K. Davis, W. Wallace, I. Lieberburg and F. Fuller, "A New A4 Amyloid mRNA Contains a Domain Homologous to Serine Protease Inhibitors," $\mathrm{Na}$ ture, Vol. 331, 1988, pp. 525-527. doi:10.1038/331525a0

[28] R. E. Tanzi, A. I. McClatchey, E. D. Lamperti, L. Villa-Komaroff, J. F. Gusella and R. L. Neve, "Protease Inhibitor Domain Encoded by Amyloid Protein Precursor mRNA Associated with Alzheimer's Disease," Nature, Vol. 331, 1987, pp. 528-530. doi:10.1038/331528a0

[29] W. E. Van Nostrand and D. D. Cunningham, "Purification of Protease Nexin II from Human Fibroblasts," Journal of Biological Chemistry, Vol. 262, No. 18, 1987, pp. 8508-8514.

[30] W. E. Van Nostrand, S. L. Wagner, M. Suzuki, B. H. Choi, J. S. Farrow and D. D. Cunningham, "Protease 
Nexin II, a Potent Antichymotrypsin, Shows Identity to Amyloid B-Protein Precursor," Nature, Vol. 341, 1989, pp. 546-549. doi:10.1038/341546a0

[31] J. M. Chernak, "Structural Features of the 5' Upstream Regulatory Region of the Gene Encoding Rat Amyloid Precursor Protein," Gene, Vol. 133, No. 2, 1993, pp. 255-260. doi:10.1016/0378-1119(93)90648-M

[32] W. J. Lukiw, E. I. Rogaev, L. Wong, G. Vaula, D. R. C. McLachlan and P. St George-Hyslop, "Protein-DNA Interactions in the Promoter Region of the Amyloid Precursor Protein (APP) Gene in Human Neocortex," Molecular Brain Research, Vol. 22, No. 1-4, 1994, pp. 121-131. doi:10.1016/0169-328X(94)90039-6

[33] B. D. Shivers, C. Hilbich, G. Multhaup, M. Salbaum, K. Beyreuther and P. H. Seeburg, “Alzheimer's Disease Amyloidogenic Glycoprotein: Expression in Rat Brain Suggests a Role in Cell Contact," EMBO Journal, Vol. 7, 1988, pp. 1365-1370.

[34] W. Song and D. K. Lahiri, "Isolation of the Genomic Clone of the Rhesus Monkey Beta-Amyloid Precursor Protein," Biochemistry and Molecular Biology International, Vol. 46, 1998, pp. 755-764.

[35] D. K. Lahiri and N. K. Robakis, "The Promotor Activity of the Gene Encoding Alzheimer B-Amyloid Precursor Protein (APP) is Regulated by Two Blocks of Upstream Sequences," Molecular Brain Research, Vol. 9, No. 3, 1991, pp. $253-257$. doi:10.1016/0169-328X(91)90009-M

[36] P. Pollwein, C. L. Masters and K. Beyreuther, "The Expression of the Amyloid Precursor Protein (APP) is Regulated by Two GC-Elements in the Promoter," $\mathrm{Nu}$ cleic Acids Research, Vol. 20, No. 1, 1992, pp. 63-68. doi:10.1093/nar/20.1.63

[37] S. Ledoux, J. Nalbantoglu and N. R. Cashman, "Amyloid Precursor Protein Gene Expression in Neural Cell Lines: Influence of DNA Cytosine Methylation," Molecular Brain Research, Vol. 24, No. 1-4, 1994, pp. 140-144. doi:10.1016/0169-328X(94)90125-2

[38] N. N. Dewji, C. Do and R. M. Bayney, "Transcriptional Activation of Alzheimer's Beta-Amyloid Precursor Protein Gene by Stress," Molecular Brain Research, Vol. 33, No. 2, 1995, pp. 245-253. doi:10.1016/0169-328X(95)00131-B

[39] R. Izumi, T. Yamada, S. Yoshikai, H. Sasaki, M. Hattori and Y. Sakaki, "Positive and Negative Regulatory Elements for the Expression of the Alzheimer's Disease Amyloid Precursor-Encoding Gene in Mouse," Gene, Vol. 112, No. 2, 1992, pp. 189-195. doi:10.1016/0378-1119(92)90375-Y

[40] M. Bourbonniere and J. Nalbantoglu, "Expression of Amyloid Precursor Protein in a Neuronal Cell Line: Functional Activity of Proximal Regulatory Elements," Molecular Brain Research, Vol. 19, No. 3, 1993, pp. 246-250. doi:10.1016/0169-328X(93)90036-O

[41] P. W. Hoffman and J. M. Chernak, "The Rat Amyloid Precursor Protein Promoter Contains Two DNA Regula- tory Elements Which Influence High Level Gene Expression," Biochemical and Biophysical Research Communications, Vol. 201, No. 2, 1994, pp. 610-617. doi:10.1006/bbrc.1994.1745

[42] S. H. Zaidi, R. Denman and J. S. Malter, "Multiple Proteins Interact at a Unique Cis-Element in the 3'-Untranslated Region of Amyloid Precursor Protein mRNA," Journal of Biological Chemistry, Vol. 269, No. 39, 1994, pp. 24000-24006.

[43] S. H. Zaidi and J. S. Malter, "Amyloid precursor Protein mRNA Stability is Controlled by a 29-Base Element in the 3'-Untranslated Region," Journal of Biological Chemistry, Vol. 269, No. 39, 1994, pp. 24007-24013.

[44] P. W. Hoffman and J. M. Chernak, "DNA Binding and Regulatory Effects of Transcription Factors SP1 and USF at the Rat Amyloid Precursor Protein Gene Promoter," Nucleic Acids Research, Vol. 23, No. 12, 1995, pp. 22292235. doi:10.1093/nar/23.12.2229

[45] M. Bourbonniere and J. Nalbantoglu, "The Helix-Loop-Helix Transcription Factor USF Interacts with the Basal Promoter of Human Amyloid Precursor Protein," Molecular Brain Research, Vol. 35, No. 1-2, 1996, pp. 304-308. doi:10.1016/0169-328X(95)00208-A

[46] M. Grilli, M. Ribola, A. Alberici, A. Valerio, M. Memo and P. Spano, "Identification and Characterization of a Kappa B/Rel Binding Site in the Regulatory Region of the Amyloid Precursor Protein Gene," Journal of Biological Chemistry, Vol. 270, No. 45, 1995, pp. 26774-26777. doi:10.1074/jbc.270.45.26774

[47] M. Grilli, F. Goffi, M. Memo and P. Spano, "Interleukinlbeta and Glutamate Activate the NF-kappaB/Rel Binding Site from the Regulatory Region of the Amyloid Precursor Protein I Primary Neuronal Cultures," Journal of Biological Chemistry, Vol. 271, No. 25, 1996, pp. 15002-15007. doi:10.1074/jbc.271.25.15002

[48] A. Odaka, T. Tsukahara, M. Momoi and T. Momoi, "C-Jun Inhibited the Alternative Splicing of Neuron-Specific Amyloid Precursor Protein, but Stimulated the Non-neuron Type One in P19 EC Cells," Biochemical and Biophysical Research Communications, Vol. 206, No. 3, 1995, pp. 831-828. doi:10.1006/bbrc.1995.1117

[49] N. Chow, J. R. Korenberg, X. N. Chen and R. L. Neve, "APP-BP1, a Novel Protein That Binds to the Carboxyl-Terminal Region of the Amyloid Precursor Protein," Journal of Biological Chemistry, Vol. 271, No. 5, 1996, pp. 11339-11346. doi:10.1074/jbc.271.19.11339

[50] N. Ramakrishna, M. Smedman and B. Gillam, "Suppression of Alzheimer Amyloid Precursor Protein (APP) Expression by Exogenous APP mRNA," Archives of Biochemistry and Biophysics, Vol. 326, No. 2, 1996, pp. 243-251. doi:10.1006/abbi.1996.0072

[51] D. Neill, A. Leake, D. Hughes, A. B. Keith, G. A. Taylor, D. Allsop, B. K. Rima, C. Morris, J. M. Candy and J. A. Edwardson, "Effect of Aluminium on Expression and Processing of Amyloid Precursor Protein," Journal of Neuroscience Research, Vol. 46, No. 4, 1996, pp. $395-$ 
403. doi:10.1002/(SICI)1097-4547(19961115)46:4<395::AIDJNR1>3.0.CO;2-B

[52] A. E. Aplin, J. S. Jacobsen, B. H. Anderton and J. M. Gallo, "Effect of Increased Glycogen Synthase Kinase-3 Activity upon the Maturation of the Amyloid Precursor Protein in Transfected Cells," Neuroreport, Vol. 8, 1997, pp. 639-643. doi:10.1097/00001756-199702100-00012

[53] M. Bourbonniere, M. Shekarabi and J. Nalbantoglu, "Enhanced Expression of Amyloid Precursor Protein in Response to Dibutyryl Cyclic AMP is Not Mediated by the Transcription Factor AP-2," Journal of Neurochemistry, Vol. 68, No. 3, 1997, pp. 909-916. doi:10.1046/j.1471-4159.1997.68030909.x

[54] G. Gegelashvili, E. Bock, A. Schousboe and D. Linnemann, "Two Types of Amyloid Precursor Protein (APP) mRNA in Rat Glioma Cell Lines: Upregulation via a Cyclic AMP-Dependent Pathway," Molecular Brain Research, Vol. 37, No. 1-2, 1996, pp. 151-156. doi:10.1016/0169-328X(95)00302-9

[55] M. Shekarabi, M. Bourbonniere, A. Dagenais and J. Nalbantoglu, "Transcriptional Regulation of Amyloid Precursor Protein During Dibutyryl Cyclic AMP-Induced Differentiation of NG108-15 Cells," Journal of Neurochemistry, Vol. 68, No. 3, 1997, pp. 970-978. doi:10.1046/j.1471-4159.1997.68030970.x

[56] S. H. Zaidi and J. S. Malter, "Nucleolin and Heterogeneous Nuclear Ribonucleoprotein C Proteins Specifically Interact with the 3'-Untranslated Region of Amyloid Protein Precursor mRNA," Journal of Biological Chemistry, Vol. 270, No. 29, 1995, pp. 17292-17298.

[57] H. H. Slunt, G. Thinakaran, C. von Koch, A. L. Y. Lo, R. E. Tanzi and S. S. Sisodia, "Expression of a Ubiquitous Cross-Reactive Homologue of the Mouse-Amyloid Precursor Protein (APP)," Journal of Biological Chemistry, Vol. 269, No. 4, 1994, pp. 2637-2644.

[58] W. Wasco, K. Bupp, M. Magendantz, J. F. Gusella, R. E. Tanzi and F. Solomon, "Identification of a Mouse Brain cDNA That Encodes a Protein Related to the Alzheimer Disease-Associated Amyloid Beta-Protein Precursor," Proceedings of the National Academy of Sciences of the United States of America, Vol. 89, No. 22, 1992, pp. 10758-10762. doi:10.1073/pnas.89.22.10758

[59] W. Wasco, S. Gurubhagavatula, M. D. Paradis, D. M. Romano, S. S. Sisodia, B. T. Hyman, R. L. Neve and R. E. Tanzi, "Isolation and Characterization of APLP 2 Encoding a Homologue of the Alzheimer's Associated Amyloid a Protein Precursor," Nature Genetics, Vol. 5, 1993, pp. 95-99. doi:10.1038/ng0993-95

[60] G. Thinakaran, C. A. Kitt, A. J. Roskams, H. H. Slunt, E. Masliah, C. von Koch, S. D. Ginsberg, G. V. Ronnett, R. R. Reed and D. L. Price, "Distribution of an APP Homolog, APLP 2, in the Mouse Olfactory System: A Potential Role for APLP in Axogenesis," Journal of Neuroscience, Vol. 15, No. 10, 1995, pp. 6314-6326.

[61] T. W. Kim, K. Wu, J. L. Xu, G. McAuliffe, R. E. Tanzi,
W. Wasco and I. B. Black, "Selective Localization of Amyloid Precursor-Like Protein 1 in the Cerebral Cortex Postsynaptic Density," Molecular Brain Research, Vol. 32 , No. 1, 1995, pp. 36-44. doi:10.1016/0169-328X(95)00328-P

[62] S. J. Harper, J. G. Bilsland, M. S. Shearman, H. Zheng, L. Van der Ploeg and D. J. Sirinathsinghji, "Mouse Cortical Neurones Lacking APP Show Normal Neurite Outgrowth and Survival Responses in Vitro," NeuroReport, Vol. 9, No. 13, 1998, pp. 3053-3058. doi:10.1097/00001756-199809140-00025

[63] M. J. McNamara, C. T. Ruff, W. Wasco, R. E. Tanzi, G. Thinakaran and B. T. Hyman, "Immunohistochemical and in Situ Analysis of Amyloid Precursor-Like Protein-1 and Amyloid Precursor-Like Protein-2 Expression in Alzheimer Disease and Aged Control Brains," Brain Research, Vol. 804, No. 1, 1998, pp. 45-51. doi:10.1016/S0006-8993(98)00653-2

[64] K. Maruyama, F. Kametani, M. Usami, W. YamaoHarigaya and K. Tanaka, "'Secretase,' Alzheimer Amyloid Protein Precursor Secreting Enzyme is Not Sequence-Specific," Biochemical and Biophysical Research Communications, Vol. 179, No. 3, 1991, pp. 1670-1679. doi:10.1016/0006-291X(91)91767-7

[65] R. Cappai, S. S. Mok, D. Galatis, D. F. Tucker, A. Henry, K. Beyreuther, D. H. Small and C. L. Masters, "Recombinant Human Amyloid Precursor-Like Protein 2 (APLP2) Expressed in the Yeast Pichia Pastoris Can Stimulate Neurite Outgrowth," FEBS Letters, Vol. 442, No. 1, 1999, pp. 95-98. doi:10.1016/S0014-5793(98)01635-4

[66] R. Siman, S. Mistretta, J. T. Durkin, M. J. Savage, T. Loh, S. Trusko and R. W. Scott, "Processing of the BetaAmyloid Precursor. Multiple Proteases Generate and Degrade Potentially Amyloidogenic Fragments," Journal of Biological Chemistry, Vol. 268, No. 22, 1993, pp. 1660216609.

[67] S. S. Sisodia, "Beta-Amyloid Precursor Protein Cleavage by a Membrane-Bound Protease," Proceedings of the National Academy of Sciences of the United States of America, Vol. 89, No.13, 1992, pp. 6075-6079. doi:10.1073/pnas.89.13.6075

[68] R. Wang, J. F. Meschia, R. J. Cotter and S. S. Sisodia, "Secretion of the Beta/A4 Amyloid Precursor Protein. Identification of a Cleavage Site in Cultured Mammalian Cells," Journal of Biological Chemistry, Vol. 266, No. 25, 1991, pp. 16960-16964.

[69] S. L. Gillespie, T. E. Golde and S. G. Younkin, "Secretory Processing of the Alzheimer Amyloid Beta/A4 Protein Precursor is Increased by Protein Phosphorylation," Biochemical and Biophysical Research Communications, Vol. 187, No. 3, 1992, pp. 1385-1290. doi:10.1016/0006-291X(92)90442-N

[70] R. Vassar, B. D. Bennett, S. Babu-Khan, S. Kahn, E. A. Mendiaz, P. Denis, D. B. Teplow, S. Ross, P. Amarante, R. Loeloff, Y. Luo, S. Fisher, J. Fuller, S. Edenson, J. Lile, M. A. Jarosinski, A. L. Biere, E. Curran, T. Burgess, J. C. Louis, F. Collins, J. Treanor, G. Rogers and M. Cit- 
ron, "Beta-Secretase Cleavage of Alzheimer's Amyloid Precursor Protein by the Transmembrane Aspartic Protease BACE," Science, Vol. 286, No. 5440, 1999, pp. 735-741. doi:10.1126/science.286.5440.735

[71] S. R. Sahasrabudhe, M. A. Spruyt, H. A. Muenkel, A. J. Blume, M. P. Vitek and J. S. Jacobsen, "Releases of Amino-Terminal Fragmentsf from Amyloid Precursor Protein Reporter and Mutated Derivatives in Cultured Cells," Journal of Biological Chemistry, Vol. 267, No. 35, 1992, pp. 25602-25608.

[72] J. Mackic, M. Weiss, W. Mhao, E. Kirkman, J. Ghiso, M. Calero, J. Bading, B. Frangione and B. V. Zlokovic, "Cerebrovascular Accumulation and Increased BloodBrain Barrier Permeability to Circulating Alzheimer's Amyloid Beta Peptide in Aged Squirrel Monkey and Cerebral Amyloid Angiopathy," Journal of Neurochemistry, Vol. 70, No. 1, 1998, pp. 210-215. doi:10.1046/j.1471-4159.1998.70010210.x

[73] K. Maruyama, Y. Kawamura, H. Asada, S. Ishiura and K. Obata, "Cleavage at the N-Terminal Site of Alzheimer Amyloid Beta/A4 Protein is Essential for Its Secretion," Biochemical and Biophysical Research Communications, Vol. 202, No. 3, 1994; pp. 1517-1523. doi:10.1006/bbrc. 1994.2103

[74] L. I. Benowitz, W. Rodriguez, P. Paskevich, E. Mufson, D. Schenk and R. L. Neve, "The Amyloid Precursor Protein is Concentrated in Neuronal Lysosomes in Normal and Alzheimer Disease Subjects," Experimental Neurology, Vol. 106, No. 3, 1989, pp. 237-250.

[75] G. L. Caporaso, K. Takei, S. E. Gandy, M. Matteoli, O. Mundigl, P. Greengard and P. De Camilli, "Morphologic and Biochemical Analysis of the Intracellular Trafficking of the Alzheimer Beta/A4 Amyloid Precursor Protein," Journal of Neuroscience, Vol. 14, No. 5, 1994, pp. 31223138.

[76] T. Dyrks, E. Dyrks, U. Monning, B. Urmoneit, J. Turner and K. Beyreuther, "Generation of Beta A4 from the Amyloid Precursor and Fragments Thereof," FEBS Letters, Vol. 335, No. 1, 1993, pp. 89-93. doi:10.1016/0014-5793(93)80446-2

[77] C. Schonlein, A. Probst and G. Huber, "Characterization of Proteases with the Specificity to Cleave at the Secretase-Site of Beta-APP," Neuroscience Letters, Vol. 161, No. 1, 1993, pp. 33-36. doi:10.1016/0304-3940(93)90133-6

[78] H. Xu, P. Greengard and S. Gandy, "Regulation Formation of Golgi Secretory Vesicles Containing Alzheimer Beta-Amyloid Precursor Protein," Journal of Biological Chemistry, Vol. 270, No. 10, 1995, pp. 23243-23245. doi: $10.1074 /$ jbc. 270.40 .23243

[79] G. Thinakaran, D. B. Teplow, R. Siman, B. Greenberg and S. S. Sisodia, "Metabolism of the 'Swedish' Amyloid Precursor Protein Variant in Neuro2a (N2a) Cells. Evidence that Cleavage at the 'Beta-Secretase' Site Occurs in the Golgi Apparatus," Journal of Biological Chemistry, Vol. 271, No. 16, 1996, pp. 9390-9397.

[80] B. De Strooper, P. Saftig, K. Craessaerts, H. Vanderstich- ele, G. Guhde, W. Annaert, K. Von Figura and F. Van Leuven, "Deficiency of Presenilin-1 Inhibits the Normal Cleavage of Amyloid Precursor Protein," Nature, Vol. 391, 1998, pp. 387-390. doi:10.1038/34910

[81] H. Xu, D. Sweeney, R. Wang, G. Thinakaran, A. C. Lo, S. S. Sisodia, P. Greengard and S. Gandy, "Generation of Alzheimer Beta-Amyloid Protein in the Trans-Golgi Network in the Apparent Absence of Vesicle Formation," Proceedings of the National Academy of Sciences of the United States of America, Vol. 94, No. 8, 1997, pp. 37483752. doi: $10.1073 /$ pnas.94.8.3748

[82] G. C. Peraus, C. L. Masters and K. Beyreuther, "Late Compartments of Amyloid Precursor Protein Transport in SY5Y Cells are Involved in Beta-Amyloid Secretion," Journal of Neuroscience, Vol. 17, No. 20, 1997, pp. 7714-7724.

[83] J. P. Greenfield, J. Tsai, G. K. Gouras, B. Hai, G. Thinakaran, F. Checler, S. S. Sisodia, P. Greengard and H. Xu, "EndoplasmicReticulum and Trans-Golgi Network Generate Distinct Populations of Alzheimer Beta-Amyloid Peptides," Proceedings of the National Academy of Sciences of the United States of America, Vol. 96, No. 2, 1999, pp. 742-747. doi:10.1073/pnas.96.2.742

[84] Y. Li, H. Wang, S. Wang, D. Quon, Y. W. Liu and B. Cordell, "Positive and Negative Regulation of APP Amyloidogenesis by Sumoylation," Proceedings of the National Academy of Sciences of the United States of America, Vol. 100, No. 1, 2003, pp. 259-264. doi: $10.1073 /$ pnas. 0235361100

[85] W. Xia, J. Zhang, B. L. Ostaszewski, W. T. Kimberly, P. Seubert, E. H. Koo, J. Shen and D. J. Selkoe, "Presenilin 1 Regulates the Processing of Beta-Amyloid Precursor Protein C-Terminal Fragments and the Generation of Amyloid Beta-Protein in Endoplasmic Reticulum and Golgi," Biochemistry, Vol. 37, No. 47, 1998, pp. 16465 16471. doi:10.1021/bi9816195

[86] G. E. Maestre, B. A. Tate, R. E. Majocha and C. A. Marotta, "Membrane Surface Ruffling in Cells that OverExpress Alzheimer Amyloid/A4 C-Terminal Peptide," Brain Research, Vol. 621, No. 1, 1993, pp. 145-149. doi:10.1016/0006-8993(93)90311-A

[87] R. Del Bo, N. Angeretti, E. Lucca, M. G. De Simoni and G. Forloni, "Reciprocal Control of Inflammatory Cytokines, IL-1 and IL-6, and B-Amyloid Production in Cultures," Neuroscience Letters, Vol. 188, No. 1, 1995, pp. 70-74. doi:10.1016/0304-3940(95)11384-9

[88] M. Citron, C. B. Eckman, T. S. Diehl, C. Corcoran, B. L. Ostaszewski, W. Xia, G. Levesque, P. St George-Hyslop, S. G. Younkin and D. J. Selkoe, "Additive Effects of PS1 and APP Mutations on Secretion of the 42-Residue Amyloid Beta-Protein," Neurobiology of Disease, Vol. 5, No. 2, 1998, pp.107-116. doi:10.1006/nbdi.1998.0183

[89] P. K. Panegyres and K. Toufexis, "Presenilin Immunoreactivity in Alzheimer's Disease," European Journal of Neurology, Vol. 12, No. 9, 2004, pp. 700-706. doi:10.1111/j.1468-1331.2005.01050.x

[90] Y. Tan, J. Hong, T. Doan, L. McConlogue and W. A. 
Maltese, "Presesnilin-1 Mutations Associated with Familial Alzheimer's Disease do not Disrupt Protein Transport from the Endoplasmic Reticulum to the Golgi Apparatus," Biochimica et Biophysica Acta, Vol. 1407, No. 1, 1998, pp. 69-78.

[91] M. E. Manni, R. Cescato and P. A. Paganetti, "Lack of Beta-Amyloid Production in M19 Cells Deficient in Site 2 Processing of the Sterol Regulatory Element Binding Proteins," FEBS Letters, Vol. 427, No. 3, 1998, pp. 367-370. doi:10.1016/S0014-5793(98)00469-4

[92] M. S. Wolfe, W. Xia, B. L. Ostaszewski, T. S. Diehl, W. T. Kimberly and D. J. Selkoe, "Two Transmembrane Aspartates in Presenilin-1 Required for Presenilin Endoproteolysis and Gamma-Secretase Activity," Nature, Vol. 398, 1999, pp. 513-517. doi:10.1038/19077

[93] Y. Shen and R. Li, "Expressing mRNAs for Presenilin-1 and Amyloid Precursor Protein (APP-695) from Same Neuronal Populations in Rat Hippocampus," Brain Research Bulletin, Vol. 46, No. 3, 1998, pp. 233-236. doi:10.1016/S0361-9230(97)00455-3

[94] D. Beher, C. Elle, J. Underwood, J. B. Davis, R. Ward, E. Karran, C. L. Masters, K. Beyreuther and G. Multhaup, "Proteolytic Fragments of Alzheimer's Disease-Associated Presenilin 1 are Present in Synaptic Organelles and Growth Cone Membranes of Rat Brain," Journal of Neurochemistry, Vol. 72, No. 4, 1999, pp. 1564-1573. doi:10.1046/j.1471-4159.1999.721564.x

[95] R. Francis, G. McGrath, J. Zhang, D. A. Ruddy, M. Sym, J. Apfeld, M. Nicoll, M. Maxwell, B. Hai, M. C. Ellis, A. L. Parks, W. Xu, J. Li, M. Gurney, R. L. Myers, C. S. Himes, R. Hiebsch, C. Ruble, J. S. Nye and D. Curtis, "APH-1 and PEN-2 are Required for Notch Pathway Signaling, Gamma-Secretase Cleavage of Betaapp, and Presenilin Protein Accumulation," Developmental Cell, Vol. 3, No. 1, 2002, pp. 85-97. doi:10.1016/S1534-5807(02)00189-2

[96] A. Weidemann, K. Paliga, U. Kurrwang, C. Czech, G. Evin, C. L. Masters and K. Beyreuther, "Formation of Stable Complexes between Two Alzheimer's Disease Gene Products: Presenilin-2 and Beta-Amyloid Precursor Protein," Nature Medicine, Vol. 3, 1997, pp. 328-332. doi:10.1038/nm0397-328

[97] W. M. Xia, J. M. Zhang, R. Perez, E. H. Koo and D. J. Selkoe, "Interaction between Amyloid Precursor Protein and Presenilins in Mammalian Cells: Implications for the Pathogenesis of Alzheimer Disease," Proceedings of the National Academy of Sciences of the United States of America, Vol. 94, No. 15, 1997, pp. 8208-8213. doi:10.1073/pnas.94.15.8208

[98] N. N. Dewji and S. J. Singer, "Specific Intercellular Binding of the Beta-Amyloid Precursor Protein to the Presenilins Induces Intercellular Signaling: Its Significance for Alzheimer's Disease," Proceedings of the National Academy of Sciences of the United States of America, Vol. 95, No. 25, 1998, pp. 15055-15060. doi:10.1073/pnas.95.25.15055

[99] W. L. Bunnell, H. V. Pham and C. G. Glabe, "Gamma-
Secretase Cleavage is Distinct from Endoplasmic Reticulum Degradation of the Transmembrane Domain of the Amyloid Precursor Protein," Journal of Biological Chemistry, Vol. 273, No. 48, 1998, pp. 31947-31955. doi:10.1074/jbc.273.48.31947

[100]Z. Kouchi, T. Kinouchi, H. Sorimachi, S. Ishiura and K. Suzuki, "The Deletion of the C-Terminal Tail and Addition of Any Endoplasmic Reticulum Targeting Signalt to Alzheimer's Amyloid Precursor Protein Change Its Localization, Secretion and Intracellular Proteolysis," European Journal of Biochemistry, Vol. 258, No. 2, 1998, pp. 291-300. doi:10.1046/j.1432-1327.1998.2580291.x

[101] P. W. Mantyh, J. R. Ghilardi, S. Rogers, E. DeMaster, C. J. Allen, E. R. Stimson and J. E. Maggio, "Aluminium, Iron and Zinc Ions Promote Aggregation of Physiological Concentrations of Beta-Amyloid Peptide," Journal of Neurochemistry, Vol. 61, No. 3, 1993, pp. 1171-1174. doi:10.1111/j.1471-4159.1993.tb03639.x

[102] L. Buee, W. Ding, J. P. Anderson and S. Narindrasorasak, "Binding of Vascular Heparan Sulfate Proteoglycan to Alzheimer's Amyloid Precursor Protein is Mediated in Part by the N-Terminal Region of A4 Peptide," Brain Research, Vol. 627, No. 2, 1993, pp. 199-204. doi:10.1016/0006-8993(93)90321-D

[103] L. Buee, W. Ding, A. Delacourte and H. Fillit, "Binding of Secreted Human Neuroblastoma Proteoglycans to the Alzheimer's Amyloid A4 Peptide," Brain Research, Vol. 601, No. 1-2, 1993, pp. 154-163. doi:10.1016/0006-8993(93)91706-X

[104] S. Bodovitz, M. T. Falduto, D. E. Frail and W. L. Klein, "Iron Levels Modulate Alpha-Secretase Cleavage of Amyloid Precursor Protein," Journal of Neurochemistry, Vol. 64, No. 1,1995, pp. 307-315. doi:10.1046/j.1471-4159.1995.64010307.x

[105] D. H. Small, R. D. Moir, S. J. Fuller, S. Michaelson, A. I. Bush, Q. X. Li, E. Milward, C. Hilbich, A. Weidemann and K. Beyreuther, "A Protease Activity Associated with Acetylcholinesterase Releases the Membrane-Bound form of the Amyloid Protein Precursor of Alzheimer's Disease," Biochemistry, Vol. 30, No. 44, 1991, pp. 10795 10799. doi:10.1021/bi00108a027

[106] D. Gabuzda, J. Busciglio, L. B. Chen, P. Matsudaira and B. A. Yankner, "Inhibition of Energy Metabolism Alters the Processing of Amyloid Precursor Protein and Induces a Potentially Amyloidogenic Derivative," Journal of Biological Chemistry, Vol. 269, No. 18, 1994, pp. 1362313628 .

[107] S. J. Lee, U. Liyanage, P. E. Bickel, W. Xia, P. T. Lansbury Jr and K. S. Kosik, "A Detergent-Insoluble Membrane Compartment Contains A Beta in Vivo," Nature Medicine, Vol. 4, 1998, pp. 730-734. doi: $10.1038 / \mathrm{nm} 0698-730$

[108] L. Ho, K. Fukuchi and S. G. Younkin, "The Alternatively Spliced Kunitz Protease Inhibitor Domain Alters Amyloid $\beta$ Protein Precursor Processing and Amyloid $\beta$ Protein Production in Cultured Cells," Journal of Biological Chemistry, Vol. 271, No. 48, 1996, pp. 30929-30934. 
[109] P. K. Panegyres, K. Zafiris-Toufexis and B. A. Kakulas, "Amyloid Precursor Protein Gene Isoforms in Alzheimer's Disease and Other Neurodegenerative Disorders," Journal of Neurological Sciences, Vol. 173, 2000, pp. 81-92. doi:10.1016/S0022-510X(99)00311-1

[110] Q. X. Li, M. C. Berndt, A. I. Bush, B. Rumble, I. Mackenzie, A. Friedhuber, K. Beyreuther and C. L. Masters, "Membrane-Associated Forms of the Beta A4 Amyloid Protein Precursor of Alzheimer's Disease Human Platelet and Brain: Surface Expression on the Activated Human Platelet," Blood, Vol. 84, No. 1, 1994, pp. 133142.

[111] Q. X. Li, G. Evin, D. H. Small, G. Multhaup, K. Beyreuther and C. L. Masters, "Proteolytic Processing of Alzheimer's Disease Beta A4 Amyloid Precursor Protein in Human Platelets," Journal of Biological Chemistry, Vol. 270, No. 23, 1995, pp. 14140-14147. doi:10.1074/jbc. 270.23 .14140

[112] H. Komano, M. Seeger, S. Gandy, G. T. Wang, G. A. Krafft and R. S. Fuller, "Involvement of Cell Surface Glycosyl-Phosphatidylinositol-Linked Aspartyl Proteases in Alpha-Secretase-Type Cleavage and Ectodomain Solubilization of Human Alzheimer Beta-Amyloid Precursor Protein in Yeast," Journal of Biological Chemistry, Vol. 273, No. 48, 1998, pp. 31648-31651. doi:10.1074/jbc. 273.48 .31648

[113] D. Le Brocque, A. Henry, R. Cappai, Q. X. Li, J. E. Tanner, D. Glaatis, C. Gray, S. Holmes, J. R. Underwood, K. Beyreuther, C. L. Masters and G. Evin, "Processing of the Alzheimer's Disease Amyloid Precursor Protein in Pichia Pastoris: Immunodetection of Alpha-, Beta- and GammaSecretase Products," Biochemistry, Vol. 37, No. 42, 1998, pp. 14958-14965. doi:10.1021/bi9810631

[114] S. Ishiura, T. Tsukahara, T. Tabira and H. Sugita, "Putative N-Terminal Splitting Enzyme of Amyloid A4 Peptides is the Multicatalytic Proteinase, Ingensin, Which is Widely Distributed in Mammalian Cells," FEBS Letters, Vol. 257, No. 2, 1989, pp. 388-392. doi:10.1016/0014-5793(89)81579-0

[115] K. Tagawa, T. Kunishita, K. Maruyama, K. Yoshikawa, E. Kominami, T. Tsuchiya, K. Suzuki, T. Tabira, H. Sugita and S. Ishiura, "Alzheimer's Disease Amyloid BetaClipping Enzyme (APP Secretase): Identification, Purification and Characterization of the Enzyme," Biochemical and Biophysical Research Communications, Vol. 177, No. 1, 1991, pp. 377-387. doi:10.1016/0006-291X(91)91994-N

[116] J. R. McDermott and A. M. Gibson, "The Processing of Alzheimer A4/Beta-Amyloid Protein Precursor: Identification of a Human Brain Metallopeptidase Which Cleaves-Lys-Leu in a Model Peptide," Biochemical and Biophysical Research Communications, Vol. 179, No. 3, 1991, pp. 1148-1154. doi:10.1016/0006-291X(91)91691-5

[117] C. Schonlein, J. Loffler and G. Huber, "Purification and Characterization of a Novel Metalloprotease from Human Brain with the Ability to Cleave Substates Derived from the N-Terminus of Beta-Amyloid Protein," Biochemical and Biophysical Research Communications, Vol. 201, No. 1, 1994, pp. 45-53. doi:10.1006/bbrc.1994.1667

[118] S. J. Fuller, E. Storey, Q. X. Li, A. I. Smith, K. Beyreuther and C. L. Masters, "Intracellular Production of Beta A4 Amyloid of Alzheimer's Disease: Modulation by Phosphoramidon and Lack of Coupling to the Secretion of the Amyloid Precursor Protein," Biochemistry, Vol. 34, No. 25, 1995, pp. 8091-8098. doi: $10.1021 / \mathrm{bi00025a015}$

[119] G. Evin, R. Cappai, Q. X. Li, J. G. Culvenor, D. H. Small, K. Beyreuther and C. L. Masters, "Candidate GammaSecretases in the Generation of the Carboxyl Terminus of the Alzheimer's Disease Beta A4 Amyloid: Possible Involvement of Cathepsin D," Biochemistry, Vol. 34, No. 43, 1995, pp. 14185-14192. doi:10.1021/bi00043a024

[120] J. S. Munger, C. Haass, C. A. Lemere, G. P. Shi, W. S. Wong, D. B. Teplow, D. J. Selkoe and H. A. Chapman, "Lysosomal Processing of Amyloid Precursor Protein to A Beta Peptides: A Distinct Role For Cathepsin S," Biochemical Journal, Vol. 311, No. 1, 1995, pp. 299-305.

[121] E. A. Mackay, A. Ehrhard, M. Moniatte, C. Guenet, C. Tardif, C. Tarnus, O. Sorokine, B. Heintzelmann, C. Nay, J. M. Remy, J. Higaki, A. Van Dorsselaer, J. Wagner, C. Danzin and P. Mamont, "A Possible Role for Cathepsins D, E and B in the Processing of Beta-Amyloid Precursor Protein in Alzheimer's Disease," European Journal of Biochemistry, Vol. 244, No. 2, 1997, pp. 414-425. doi:10.1111/j.1432-1033.1997.00414.x

[122] R. N. LePage, A. J. Fosang, S. J. Fuller, G. Murphy, G. Evin, K. Beyreuther, C. L. Masters and D. H. Small, "Gelatinase A Possesses a Beta-Secretase-Like Activity in Cleaving the Amyloid Protein Precursor of Alzheimer's Disease," FEBS Letters, Vol. 377, No. 2, 1995, pp. 267-270. doi:10.1016/0014-5793(95)01358-X

[123] S. P. Little, E. P. Dixon, F. Norris, W. Buckley, G. W. Becker, M. Johnson, J. R. Dobins, T. Wyrick, J. R. Miller, W. MacKellar, D. Hepburn, J. Corvalan, D. McClure, X. Liu, D. Stephenson, J. Clemens and E. M. Johnstone, "Zyme, a Novel and Potentially Amyloidogenic Enzyme Cdna Isolated from Alzheimer's Disease Brain," Journal of Biological Chemistry, Vol. 272, No. 40, 1997, pp. 25135- 25142. doi:10.1074/jbc.272.40.25135

[124] J. D. Buxbaum, K. N. Liu, Y. Luo, J. L. Slack, K. L. Stocking, J. J. Peschon, R. S. Johnson, B. J. Castner, D. P. Cerretti and R. A. Black, "Evidence That Tumor Necrosis Factor Alpha Converting Enzyme is Involved in Regulated Alpha-Secretase Cleavage of the Alzheimer Amyloid Protein Precursor," Journal of Biological Chemistry, Vol. 273, No. 43, 1998, pp. 27765-27767. doi:10.1074/jbc. 273.43 .27765

[125] A. Weidemann, K. Paliga, U. Drrwang, F. B. Reinhard, O. Schuckert, G. Evin and C. L. Masters, "Proteolytic Processing of the Alzheimer's Disease Amyloid Precursor Protein within Its Cytoplasmic Domain by Caspase-Like Proteases," Journal of Biological Chemistry, Vol. 274, No. 9, 1999, pp. 5823-5829. doi:10.1074/jbc.274.9.5823 
[126] Y. H. Chong, J. M. Jung, W. Choi, C. W. Park, K. S. Choi and Y. H. Suh, "Bacterial Expression, Purification of Full Length and Carboxyl Terminal Fragment of Alzheimer Amyloid Precursor Protein and Their Proteolytic Processing by Thrombin," Life Sciences, Vol. 54, No. 17, 1994, pp. 1259-1268. doi:10.1016/0024-3205(94)00853-1

[127] Y. Yang, R. S. Turner and J. R. Gaut, "The Chaperone BiP/GRP78 Binds to Amyloid Precursor Protein and Decreases Abeta40 and Abeta42 Secretion," Journal of Biological Chemistry, Vol. 273, No. 40, 1998, pp. 25552-25555. doi:10.1074/jbc.273.40.25552

[128] J. P. Borg, S. W. Straight, S. M. Kaech, M. de Taddeo-Borg, D. E. Kroon, D. Karnak, R. S. Turner, S. K. Kim and B. Margolis, "Identification of an Evolutionarily Conserved Heterotrimeric Protein Complex Involved in Protein Targeting," Journal of Biological Chemistry, Vol. 273, No. 48, 1998, pp. 31633-31636. doi:10.1074/jbc.273.48.31633

[129] J. P. Borg, Y. Yang, M. de Taddeo-Borg, B. Margolis and R. S. Turner, "The X11 Alpha Protein Slows Cellular Amyloid Precursor Protein Processing and Reduces Abeta40 and Abeta42 Secretion," Journal of Biological Chemistry, Vol. 273, No. 24, 1998, pp. 14761-14766. doi:10.1074/jbc.273.24.14761

[130] P. Zheng, J. Eastman, S. Vande Pol and S. W. Pimplikar, "PAT1, a Microtubule-Interacting Protein, Recognizes the Basolateral Sorting Signal of Amyloid Precursor Pro- tein," Proceedings of the National Academy of Sciences of the United States of America, Vol. 95, No. 25, 1998; pp. 14745-14750. doi:10.1073/pnas.95.25.14745

[131] T. Watanabe, J. Sukegawa, I. Sukegawa, S. Tomita, K. Iijima, S. Oguchi, T. Suzuki, A. C. Nairn and P. Greengard, "A 127-kDa Protein (UV-DDB) Binds to the Cytoplasmic Domain of the Alzheimer's Amyloid Precursor Protein," Journal of Neurochemistry, Vol. 72, No. 2, 1999, pp. 549-556. doi:10.1046/j.1471-4159.1999.0720549.x

[132] S. Tomita, T. Ozaki, H. Taru, S. Oguchi, S. Takeda, Y. Yagi, S. Sakiyama, Y. Kirino and T. Suzuki, "Interaction of a Neuron-Specific Protein Containing PDZ Domains with Alzheimer's Amyloid Precursor Protein," Journal of Biological Chemistry, Vol. 274, No. 4, 1999, pp. 2243-2254. doi: $10.1074 / \mathrm{jbc} .274 .4 .2243$

[133] V. Y. Hook, C. Sei, S. Yasothornsrikul, T. Toneff, Y. H. Kang, S. Efthimiopoulos, N. K. Robakis and W. Van Nostrand, "The Kunitz Protease Inhibitor Form of the Amyloid Precursor Protein (KPI/APP) Inhibits the Proneuropeptide Processing Enzyme Prohormone Thiol Protease (PTP). Colocalization of KPI/APP and PTP in Secretory Vesicles," Journal of Biological Chemistry, Vol. 274, No. 5, 1999, pp. 3165-3172. doi:10.1074/jbc.274.5.3165 